\title{
“OH! LET THE BOYS FIGHT, IT'S IN THEIR NATURE” - A STUDY ON GENDER STEREOTYPES IN REGARDS TO PUNISHMENT MEASURES
}

S. DUTEIL DEYRIES
$\begin{gathered}\text { University of Montpellier (France) } \\ \text { duteil.sophie@gmail.com }\end{gathered}$
Manuscript received in December/2015 and accepted in December/2015
DOI: $10.15628 /$ holos.2015.3791

\begin{abstract}
As demonstrated by a number of studies on the construction of gender roles, school staffs continue to discriminate, in a number of ways, between girls and boys. The male pupils and the female pupils are not considered or handled in the same way, and punishment is an important part of this discriminatory system. The study aims to show, through the example of punishment, how girls and boys are subjected to gender-specific conditioning in a high-school of the region of Montpellier (South of France). By basing itself both on quantitative methodologies (questionnaires, study of
\end{abstract}

archives and of the use of certain "words" [disciplinary remarks] in the pupil report cards) and qualitative ones (discussion with the teachers), the study at hand gives cause for statistics and thematic analysis, demonstrating how the behavior of adults and pupils is both discriminating and discriminated against. Several hypotheses allow one to grasp what takes place when a punishment is handed out to a pupil and what it furthers in the child, the adult, and their peers. This study was conducted in France, as final thesis of a Master's degree.

KEYWORDS: Gender; education; punishment; stereotype.

\section{“OH! DEIXE OS MENINOS BRIGAREM, ESTÁ NA NATUREZA DELES!” - UM ESTUDO SOBRE ESTEREÓTIPOS DE GÊNERO EM RELAÇÃO ÀS MEDIDAS DE PUNIÇÃO}

\section{RESUMO}

Conforme demonstrado por um número de trabalhos sobre a construção de papéis de gênero, os profissionais da educação continuam a discriminar, num certo número de práticas, meninas e meninos. Os alunos de um ou de outro sexo não são considerados e tratados da mesma maneira. A punição é parte deste sistema discriminatório. O texto examina como meninos e meninas são submetidas a um condicionamento através da punição, condicionamento este pensado segundo o gênero. Realizado em uma escola de Ensino Médio localizada em Montpellier (França), a pesquisa realizouse com base em metodologias quantitativas (questionários, estudo de arquivos e de "recados" [observações disciplinares] em agendas escolares) e qualitativas (entrevistas com professores), o estudo realizado, resultando em dados estatísticos e análise temática de conteúdo, mostra que os comportamentos dos adultos e dos alunos são discriminados e discriminatórios. Várias hipóteses permitem compreender o que se põe em jogo quando uma punição é imposta e o que ela gera nas crianças, nos adultos e em seus pares. Este trabalho se constituiu no manuscrito de conclusão do mestrado 2 na França.

PALAVRAS-CHAVE: Gênero; educação; punição, estereótipo. 


\section{THE RESEARCH IN CONTEXT AND THEORETICAL STRUCTURE}

Today, it is undeniable that social diversity in schools is not enough to guarantee and promote equality between genders. Nevertheless, the question is central in secondary schools of the Department of Education in France. The specific item under scrutiny in this article is the punitive devices set in place in high schools. Figures on the number of sanctions and punishments in school circles show every year an important disequilibrium : $80 \%$ of the punished pupils are boys (Ayral, on 2011).

The researcher works as a Conseiller Principal d'Education or CPE (the job is specific to the French educational system but is similar the Anglo-Saxon Educational Adviser) and by default, her work is linked to the notions of punishment and penalty due to its cultural heritage : working as an educational supervisor. Today, even though the job has undergone considerable evolution, leaning more towards educating and supporting the pupil, both at school and at home, as well as the fostering of school life and the cooperation between educational actors and foreign partners, punishments and sanctions remain central in a CPE's everyday work. Because of the CPE's particular position within the school, at the crossroads of many different interactions, she is a privileged witness of how boys in particular evolve within the punitive system.

The study will first center on punishment rather than sanction, as I will analyze essentially the exclusions from class, the study of the chosen "words" in the pupil report cards as well as the rebuking by teachers. However the notion of sanction will also be observed due to the fact that disparities based on pupil genders are essentially the same, whether a punishment or a sanction is applied.

S. Ayral's ${ }^{1}$ study provided the starting point: boys are more often punished than girls as they are more likely to disrupt the "school order" and its rules. In a different social and cultural context, the goal of the study will either be to confirm or dispute S. Ayral's analysis (2011), which portrays punishment as a discriminating measure that sets boys into a caricatural male identity while strengthening the behaviors it strives to correct. It will also question adults in their actions regarding these disparities.

\section{THE ISSUE OF GENDER AT THE CENTER OF THE SCHOOLING SYSTEM}

The never ending process of gender discrimination has efficiently established a series of values linked to self-representations, expectations and behaviors, which have over time been interiorized by the children (Baudelot \& Establet study, 2007). Schools hold a central place in the transmission of gender stereotypes through practice, teaching methods and educational teams, and as set forth by N. Mosconi (2004), its hidden curriculum also includes the establishment of pupils' gender identity within society. The fact stands that this gender identity has given way to a system in which one gender undermines the other, as male and female stereotypes prove to be profoundly asymmetrical: by valuing the dominant group (male) and undermining the dominated group (female) (Bourdieu, 1998), it contributes to the crystallization of so-called social positions for both women and men.

\footnotetext{
${ }^{1}$ The author published in 2011 « La fabrique des garçons »
} 
Gender division takes place as early as preschool (Mosconi, 2001) and perhaps even as the child exits the mother's womb (Bellotti, 1974). The sound space is dominated by boys. In classrooms, girls build themselves in opposition to the male gender (Monnot, on 2013). If boys are noisy, fight-fueled, then girls learn to be discreet. They do not develop the same competitive spirit.

In class, boys demand more attention and assistance from the teachers, who have a tendency to neglect the girls. In turn, the female pupils will learn to be more autonomous. This aspect favors the superior success ratings of girls at school, particularly in primary education.

Teachers are more attentive to boys' needs. Male pupils are questioned more often and considered individually, whereas girls tend to be treated as a group. The consequence of this attention towards boys results in girls being less stimulated, receiving fewer encouragements and open questions from the teachers (Mosconi, on 2001). As a result, they depreciate themselves more easily.

There are no differences in significant skills between girls and boys. On the other hand there clearly is a difference when it comes to teachers' behavior and the pupils themselves when confronted with their own education (Duru-Bella, 1994). N. Mosconi's 2/3-1/3 law (2001) within classrooms. According to a survey conducted in nursery schools by C. de Boissieu (2009) "children will learn to become [...] girl pupils or boy pupils" (p. 13).

However K. Isabelle (2010) casts a different look on this statement: the law expressed above is refuted when expressing a certain balance in the treatment of a girl or boy by the teacher. The survey also questions the fact that the teacher's gender has but little importance when the issue of gender stereotypes arise. These results question the school structure in general as well as its excessive feminization. From this stemmed J.-L. Auduc's interrogations (2009) regarding the fact that occupations centering around children and adolescents were feminizing themselves. During their school years, boys have but very few male models they can identify with. Finally, studies on the secondary education system (Mosconi, 1989) have highlighted the fact that schools use the "neutral-male" figure which, on behalf of promoting equality at school, re-enact both male values and power. In these conditions, would there be a "neutral-male" figure regarding school punishment?

\section{THE GENDER « PUNISHMENT DEVICE » ${ }^{2}$ IN SCHOOL PUT TO THE TEST}

For a long time French social sciences have failed to take into consideration the gender variable in their studies and to this day, this variable linked to punishment in school almost does not exist. Punishment have been forever present in the history and functioning of the French educational system, even if it tends to evolve thanks to reforms attempting to make schools more efficient. According to E. Prairat (1997), a sanction is a good analyzer of the educative action. "Tell me how you punish, and I will tell you how you educate" (Prairat, 1997, p.11). A sanction is defined as "an act through which one makes amends for a behavior that has endangered social standards, laws, values, or any person in an established group". The sanction and the punishment do not have the same purpose: a punishment serves to discourage a behavior, whereas a sanction has an educational value. Transgressions are addressed by

\footnotetext{
${ }^{2}$ Expression used by Sylvie Ayral
} 
punishment or sanction, according to the breach's seriousness or multiplicity. "Most transgressions appear less as behavioral problems linked to socio-educational issues, than as gender ritualized conducts" (Ayral, 2011: p. 43).

S. Ayral's report (2011) reads as following: $4 / 5^{\text {th }}$ of sanctions were handed out to boys. In the light of this, it is difficult to believe in an equal treatment of genders within schools. Is punishment reserved only for boys?

On a more global scale, the official purpose of a sanction is to give the pupil a sense of responsibility regarding his actions. By giving him the opportunity to reflect on his behavior and become gradually aware of the consequences, he is also reminded of the necessity of the law and the requirements of community life. However, according to J. Bread (1972), punishment and sanctions are not in the least educational and are seen more as a way of diminishing the pupil's self-esteem.

When observing and questioning pupil behaviors, one may notice that punishment also carries more insidious consequences. S Ayral (2011) relates her meeting in a private school with an $8^{\text {th }}$ grader who had excellent marks:

\footnotetext{
"It shows that they can act stupidly, that it's heated because they get expelled. It's sweet to them because they can get all the girls [...] me for example, I don't like bookworms, I prefer those who fu....who horse around, it's more fun" (Ayral, 2011, p. 42).
}

In effect, the consequences are far from the official purposes... The promoted attitude of government officials since 2000 has been gender equality and the refusal of discriminations. However one cannot help but notice gender equality in the face of punishment is not respected. Sanctions are present in three sectors within the educational system: educational and educative authority, knowledge, and socialization (Ayral, 2011).

In junior high school, boys are caught between two adaptative constraints : on the one hand they have to respect the "living together " moto and discipline (Foucault, 1975), that is to say the school rules that bind all pupils. On the other hand, they are expected to show a manliness that society urges them to express, which is in turn used by their peers. These behaviors encourage sexist and homophobic behaviors between pupils.

These behaviors can be found in both educational and educative relations, and can be submitted to gender (a male pupil and a female teacher for example). The stakes will therefore be very different for the adult and the pupil. S Ayral (2011) reports five of these sanctions:

- Sanction as a gender diversification ritual. Asserting one is a boy and not a girl through one's behavior.

- Sanction as a binding ritual. This is a testament to the "manliness standards".

- Sanction as a rite of passage. A way of entering a group of "great men", considered as being "superior".

- The search of the sanction is also a male parade to approach girls. The " metaphorical opportunity to show off one's sexual attributes" (Ayral, 2011, p. 43). 
- Sanction as the quest for integration into a group of peers. It is a social behavior rather than a divergent one.

In 2004, N. Mosconi quoted M. Desplats (1989):

"Teachers consider behavior and results according to a " double standard ", tolerating boys' lack of discipline while stigmatizing the girls', linking female performance to their work and male performance to their capabilities".

\section{RESEARCH METHODOLOGY}

This study centered on a variety of points: to begin with, it was important to acknowledge wether or not the pupils held on to the same stereotypes as adults regarding women and men. In order to achieve this, the study was inspired by William \& Bennett's (1975) which listed the various qualifiers associated with male and feminine stereotypes.

For three weeks, the pupils in free period were given the instruction to fill out a document describing five qualifiers to characterize a girl and a boy of their age. In parallel, a study of the pupil report cards was made in order to analyze precisely what "words" were used by the teachers in addressing the parents. For a two months period, report cards were selected randomly to check if precise behaviors for both girls and boys had been reported. At the same time, the contribution of a few motivated teachers was requested. It was asked that they pay attention to their own remarks for a period of two weeks in order to answer the following question: do the reprimands address girls or boys? Did they analyze their feedback afterwards, and in particular their reactions and point of view regarding differentiated punishment according to pupil gender. Finally, a qualitative analysis of this content was made piecing together the cases in the various report cards.

Twenty-four teachers within the school were interviewed to find out how many times a day, on average, they wrote "a note" destined to the parents in the pupils' report cards. The answer, in fact, is twice. This multiplied by the number of teachers allows for a daily-hour survey, twice a week, showing a string of new incoming "notes". These tend to repeat themselves : "your child still does not have his equipment", "yet again your child has not done his homework, same as last week", or are somewhat out of the ordinary: "I do not tolerate being insulted", "once again, your child is chatting in class, which I do not allow, yet he carries on despite my continuous remarks". By analyzing the "notes" used by the teachers in the different report cards it is possible to judge if one is faced with gender discrimination or not (Ayral, 2011). With this in mind, for the month of January and part of February 2014, the "notes" in the report cards of both girls and boys (6 ${ }^{\text {th }}$ to $9^{\text {th }}$ graders) were listed.

Having asked the teachers the average number of "notes" they drafted, the question must be specified as such: "Are the majority of "notes" addressed to girls or boys ?". Out of the twenty-four teachers, sixteen stated that they wrote as many for girls as for boy. Five teachers answered that it was to a majority of boys, and three gathered that it was a study on gender and expressed it. One teacher stated : "Yes, in truth boys are punished more often and that is not a good thing. But at the same time they are so noisy and disruptive. I don't know how to stop them. You are studying gender it that it ?". It is to be noted that out of these three teachers, two were women. By default and by making me understand they did not plan on answering the survey, these three were excluded from the sample. 
It was asked of the twenty-one remaining teachers to notice, when drafting their "notes" in the report card, if they were addressing a girl or a boy. Two weeks later, the researcher contacted them again to know if the device had been set in place and what results it had given. Nine teachers had not implemented the procedure, but the other twelve had followed the direction. Out of these twelve, seven were women and five were men.

Finally, to know the gender of the pupils expelled from class (as well as the reasons) and that of the punishing teachers, the school archives were scrutinized, from the beginning of September 2013 to mid-March 2014 : 1078 individual pupil files (digital version) were collected. This sample is composed of 532 girls $(49,4 \%)$ and of 546 boys $(50,6 \%)$.

Chart 1: Number of pupils by grade and gender in the high school (individual files collected)

\begin{tabular}{|c|c|c|c|c|c|c|c|}
\hline $\begin{array}{l}6^{\text {th }} \text { graders: } \\
265 \text { pupils }\end{array}$ & & $\begin{array}{l}7^{\text {th }} \text { graders : } \\
252 \text { pupils }\end{array}$ & & $\begin{array}{l}8^{\text {th }} \text { graders } \\
271 \text { pupils }\end{array}$ & & $\begin{array}{l}9^{\text {th }} \text { graders : } \\
290 \text { pupils }\end{array}$ & \\
\hline Girls & Boys & Girls & Boys & Girls & Boys & Girls & Boys \\
\hline 131 & 134 & 127 & 125 & 139 & 132 & 135 & 155 \\
\hline
\end{tabular}

The second point of interest was the number of teachers in the school as well as the distribution between men and women: 80 teachers among which 25 men (31\%) and 55 women (69\%). This gender imbalance must be taken into account.

\section{RESULTS AND ANALYSIS}

\subsection{Girls and boys facing their own stereotypes}

The following chart lists the answers collected for the study on the five qualifiers attributed to both women and men. The four adjectives used more than ten times by the pupils are the same for the $7^{\text {th }}, 8^{\text {th }}$ and $9^{\text {th }}$ graders and the results significantly illustrate the stereotypical vision said pupils have.

Chart 2: The boys and the girls' answers

\begin{tabular}{|c|c|c|c|c|}
\hline \multirow[b]{2}{*}{$6^{\text {th }}$ graders } & \multicolumn{2}{|l|}{ BOYS } & \multicolumn{2}{|l|}{ GIRLS } \\
\hline & Boys & Girls & Boys & Girls \\
\hline & $\begin{array}{l}\text { Fighter (more than } \\
15 \text { times) } \\
\text { Strong }\end{array}$ & $\begin{array}{l}\text { Shy } \\
\text { Moody }\end{array}$ & $\begin{array}{l}\text { Authoritarian (+10) } \\
\text { Proud } \\
\text { Arrogant } \\
\text { Fighter } \\
\text { Brutal }\end{array}$ & $\begin{array}{l}\text { Sensitive (+15) } \\
\text { Shy (+15) } \\
\text { Stylish } \\
\text { Fearful } \\
\text { Nice }\end{array}$ \\
\hline $7^{\text {th }}$ graders & Boys & Girls & Boys & Girls \\
\hline & $\begin{array}{l}\text { Funny }(+\mathbf{1 0}) \\
\text { Sporty }(+15) \\
\text { Anxious } \\
\text { Dumb } \\
\text { Brutal } \\
\text { Cool }\end{array}$ & $\begin{array}{l}\text { Smart }(+10) \\
\text { Talkative }(+10) \\
\text { Bitchy }(+10) \\
\text { Shy }(+15) \\
\text { Romantic } \\
\text { Demanding } \\
\text { Focused }\end{array}$ & $\begin{array}{l}\text { Dumb (+10) } \\
\text { Macho }(+10) \\
\text { Immature }(+10) \\
\text { Sporty }(+15) \\
\text { Funny } \\
\text { Proud } \\
\text { Disorganized } \\
\text { Arrogant }\end{array}$ & $\begin{array}{l}\text { Focused (+10) } \\
\text { Shy }(+15) \\
\text { Sensitive }(+10) \\
\text { Romantic } \\
\text { Reasonable } \\
\text { Funny } \\
\text { Vindictive } \\
\text { III at ease (because } \\
\text { of boys) } \\
\text { Well kept }\end{array}$ \\
\hline
\end{tabular}




\begin{tabular}{|c|c|c|c|c|}
\hline & & & & $\begin{array}{l}\text { Tidy } \\
\text { Stylish }\end{array}$ \\
\hline \multirow[t]{7}{*}{$8^{\text {th }}$ graders } & Boys & Girls & Boys & Girls \\
\hline & Sporty (+15) & Shy (+15) & Dumb (+10) & Shy $(+15)$ \\
\hline & Flirty $(+10)$ & Elegant & Funny (+10) & Feminine \\
\hline & Provocative $(+10)$ & Thoughtful & Sporty (+15) & Gossipy \\
\hline & Fighter & Hard-working & Immature $(+10)$ & Moody \\
\hline & Immature & Persuasive & Macho & Mature \\
\hline & & Mature & Selfish & \\
\hline \multirow[t]{11}{*}{$9^{\text {th }}$ graders } & Boys & Girls & Boys & Girls \\
\hline & Sporty (+15) & Shy (+15) & Immature (+10) & Shy (+15) \\
\hline & Fighter (+15) & Friendly (+10) & Protective $(+10)$ & Touchy (+10) \\
\hline & Show off $(+10)$ & Sensitive (+15) & Proud & Jealous (+10) \\
\hline & Manly (+10) & Feminine $(+10)$ & Funny & Talkative $(+10)$ \\
\hline & Party-goer & Talkative & Obsessive & Carefree \\
\hline & Gentlemanly & Respectful & & Responsible \\
\hline & & Bitchy & & Bitchy \\
\hline & & Nice & & Stressed \\
\hline & & Sissy & & Calm \\
\hline & & Stressed & & \\
\hline
\end{tabular}

The two recurring adjectives used by boys are : "fighter" and "sporty", while for girls, they are "sensitive" and "shy". The $6^{\text {th }}$ graders proved to be an exception because the number of participants was probably not significant enough, even though three of the four adjectives (fighter, sporty, sensitive and shy) are associated within the qualifiers "shy, sensitive and fighter".

The $6^{\text {th }}$ grader boys emphasize being "fighters" first, while the $6^{\text {th }}$ grader girls qualify themselves as being both "sensitive" and "shy". Some of the boys are often self-appointed "leaders": they are the ones who lead the way on playgrounds.

The vast majority of the $7^{\text {th }}$ grader boys use the term "sporty" and "funny" to describe themselves, while using the adjective "shy" when mentioning girls. "Bitchy" and "talkative" are also quoted many times (more than 25 times). The girls think of themselves as being "shy" and "sensitive", but also "serious". As for the boys, they are described are being "sporty", "macho" and "immature".

The $8^{\text {th }}$ grader boys are, according to their own statements; "sporty", "flirty" and "provocative". They coin the girls as being "shy" before anything else. In fact, the girls also say of themselves that they are "shy", and generally qualify boys as being "sporty", "funny" and "immature".

Finally, the $9^{\text {th }}$ grader boys say that they are "sporty" and "fighters", but also "manly" and "show offs". They find girls to be "shy", "sensitive", "friendly" and "feminine". The girls think of themselves as being "shy", "susceptible", "talkative", and "jealous", and coin the boys as being both "immature" and "protective".

Although four adjectives recur for nearly every grade $\left(6^{\text {th }}, 7^{\text {th }}, 8^{\text {th }}\right.$ and $9^{\text {th }}$ graders), a noteworthy evolution can be seen when looking at the perception of girls and boys in different stages of their development : for example, the girls start by viewing the boys as being "leaders", 
usually "deciding on everything". This rapidly merges into perceiving a "macho" and "immature" side to them, before finally seeing them as "funny" and "protective". From the boys' perspective, they begin by seeing girls as "bitchy" and "talkative", merging over the years into finding them "nice" and "feminine".

The gap separating $6^{\text {th }}$ grader girls and boys, whether in games or in the creation of a group of friends, evolves with their development. During high school and on account of budding sexuality, each gender ceases to view the other as an intruder, and tries instead to create proximity.

It is necessary to emphasize such adjectives as "dumb" and "smart/hardworking/serious". The $7^{\text {th }}$ grader boys find themselves to be "dumb" while girls are coined "smart". At the same time, the $7^{\text {th }}$ grader girls declare that boys are "stupid" whilst thinking of themselves as "serious".

The column representing the $8^{\text {th }}$ grader pupils is essentially the same for the $7^{\text {th }}$ graders. This mirroring effect is revealing of the unrest boys have suffered from in school over the past few years. Well before 2009 and ongoing today, PISA studies have set in evidence the gap between girls' and boys' success rates (which can loosely be understood by the fact that girls are one year ahead of boys in reading, and three months ahead in mathematics). Even though the girls' successful school paths usually result in their elimination from scientific fields (Baudelot \& Establet, 1998: p. 34), J.-L. Auduc (2009) notes : "School is undoubtedly the place where being of kind male is a disqualifying characteristic" (Auduc, 2009: p. 34). In light of these various points, and thanks to the answers given by the pupils, both boys and girls would clearly have taken on the role they were attributed to within the school system : the girls as "good pupils " while the boys stayed behind.

\subsection{Teachers and the pupil report card}

Chart 3: Chart on teachers' results regarding inter-personal pratices towards pupils

\begin{tabular}{|c|c|c|}
\hline \multirow{3}{*}{$\begin{array}{l}\text { Profiles } \\
\text { French teacher }\end{array}$} & \multirow[b]{2}{*}{ Results } & \multirow[t]{2}{*}{ Reactions } \\
\hline & & \\
\hline & $\begin{array}{l}\text { Before : equal } \\
\underline{\text { After }:+ \text { boys }}\end{array}$ & $\begin{array}{l}\text { Surprised at the wideness of gap } \\
\text { between boys and girls. Feels a } \\
\text { little guilty. }\end{array}$ \\
\hline History/Geography teacher & $\begin{array}{l}\text { Before : + boys } \\
\underline{\text { After : + boys }}\end{array}$ & $\begin{array}{l}\text { Thinks boys need to be more } \\
\text { focused. They are not as mature as } \\
\text { girls. }\end{array}$ \\
\hline French teacher & $\begin{array}{l}\text { Before : + boys } \\
\text { After : + boys }\end{array}$ & $\begin{array}{l}\text { Girls are more skilled in this } \\
\text { subject, whereas boys grow } \\
\text { disinterested with it faster. } \\
\text { Consequently they are given more } \\
\text { notes in their report cards. }\end{array}$ \\
\hline German teacher & $\begin{array}{l}\text { Before: + boys } \\
\text { After : equal }\end{array}$ & $\begin{array}{l}\text { Believes she is tougher on } \\
\text { discipline and works with boys, yet } \\
\text { the experimentation revealed that } \\
\text { she, in fact, was not. }\end{array}$ \\
\hline Math teacher & $\begin{array}{l}\text { Before: + boys } \\
\text { After : + boys }\end{array}$ & $\begin{array}{l}\text { Takes full responsibility in } \\
\text { punishing the boys more, and does } \\
\text { not put into question his methods. }\end{array}$ \\
\hline
\end{tabular}




\begin{tabular}{|c|c|c|}
\hline Arts teacher & $\begin{array}{l}\text { Before: equal } \\
\underline{\text { After : equal }}\end{array}$ & $\begin{array}{l}\text { Very attentive on the issue of } \\
\text { punishment, she was always careful } \\
\text { to treat both girls and boys equally. }\end{array}$ \\
\hline Music teacher & $\begin{array}{l}\text { Before : equal } \\
\text { After : + girls }\end{array}$ & $\begin{array}{l}\text { Surprised by the results, even } \\
\text { though she considers herself } \\
\text { tougher with girls, because "boys } \\
\text { just don't care about the art of } \\
\text { music ". }\end{array}$ \\
\hline History/Geography teacher & $\begin{array}{l}\text { Before: equal } \\
\underline{\text { After : equal }}\end{array}$ & $\begin{array}{l}\text { Concerned about pupil equality et } \\
\text { was not surprised by the results. } \\
\text { Makes fun of the results of his } \\
\text { colleague the music teacher. }\end{array}$ \\
\hline Math teacher & $\begin{array}{l}\text { Before : + boys } \\
\text { After : + boys }\end{array}$ & $\begin{array}{l}\text { Unimpressed, as boys prove less } \\
\text { disciplined than girls, and therefore } \\
\text { more prone to punishment. }\end{array}$ \\
\hline French teacher & $\begin{array}{l}\text { Before: : equal } \\
\text { After : equal }\end{array}$ & $\begin{array}{l}\text { Doesn't believe in discrimination } \\
\text { through punishment and sanction. }\end{array}$ \\
\hline Technology teacher & $\begin{array}{l}\text { Before : + boys } \\
\text { After : equal }\end{array}$ & $\begin{array}{l}\text { Satisfied with the result, although } \\
\text { implemented the procedure only } \\
\text { two weeks prior. Promises to } \\
\text { continue paying attention to the } \\
\text { issue. }\end{array}$ \\
\hline English teacher & $\begin{array}{l}\text { Before : + boys } \\
\text { After : + girls }\end{array}$ & $\begin{array}{l}\text { His explanation goes as following : } \\
\text { the girls in his class this year are } \\
\text { insufferable. He nonetheless } \\
\text { believes he punishes the boys } \\
\text { more, and is generally tougher in } \\
\text { the sanctions he hands out to } \\
\text { them. }\end{array}$ \\
\hline
\end{tabular}

The results prove extremely varied and it is therefore difficult to draw a general conclusion. Seven teachers thought they were more prone to punishing boys. No teacher thought he or she was punishing the girls more, and only five thought they were punishing boys and girls equally.

The results show a significant disparity between perception and reality: five teachers punished the boys more, two punished the girls more, and five punished the girls as much as the boys. These results are to be put in perspective on account of the short period of time (two weeks) and small sample (only $11 \%$ of the teachers) of the survey. Regarding this, it must be noted that the short period during which the devices were asked to be implemented was linked to the concern that certain teachers might either forget the task entirely or implement it less and less over time.

A study on education can turn into a study on gender if the teacher and pupil do not share the same gender (Ayral, 2011: p. 43). The transgression of rules in order to assert oneself comes in direct opposition to a gender, not a teacher, and this analysis can therefore serve to explain certain of the survey's results regarding teachers.

Parallel to this survey, a qualitative analysis of the lexical terms used by the teachers in the report cards was implemented. It concerned 83 pupils and regarded their behavior in class. There proved to be no particular discriminating motives in the report cards, with the exception 
of: "forgetting a binder/exercise book again" and "homework not done", which recurred very often for girls, and the word "arrogance", used only for boys. Violence, disrespect, or the degradation of school equipment are therefore not "criticism" made specifically to boys. In the same way, the use of cellphones and chatting are not devolved solely to women. Is it therefore possible to draw any conclusion from the contents of these report card "notes", collected randomly? There is probably not enough subject matter or enough proof to be sure that at this moment, regarding this school and this sample of pupils, there isn't a clearly identifiable gender motive. A girl can fight and prove to be violent, just as it simply cannot be stated that boys are, as a rule, less talkative than their female companions.

\subsection{Class exclusion as viewed through the school archives}

The archive analysis gave way to more significant results. From these, three points were observed: first of all, the difference between girls and boys regarding exclusion, secondly the types of exclusion, and finally the impact of the teacher's gender.

\subsubsection{Noticing the differences between girls and boys}

The important distinction to bear in mind can be defined as following : the difference between the number of exclusions in total and the number of exclusion per pupil. The chart below relates the number of exclusions according to the pupil's gender (girl/boy) and their grade $\left(6^{\text {th }}, 7^{\text {th }}, 8^{\text {th }}\right.$ or $9^{\text {th }}$ grade).

One can clearly notice the superiority of the number of boy exclusions, in every grade. In fact these numbers grow till $8^{\text {th }}$ grade, when they stabilize. Girls on the other hand, take on an increasing number of exclusions as they move on from one grade to the next. It is in the $9^{\text {th }}$ grade that they are expelled the most.

Chart 4: Number of expelled pupils per grade and gender

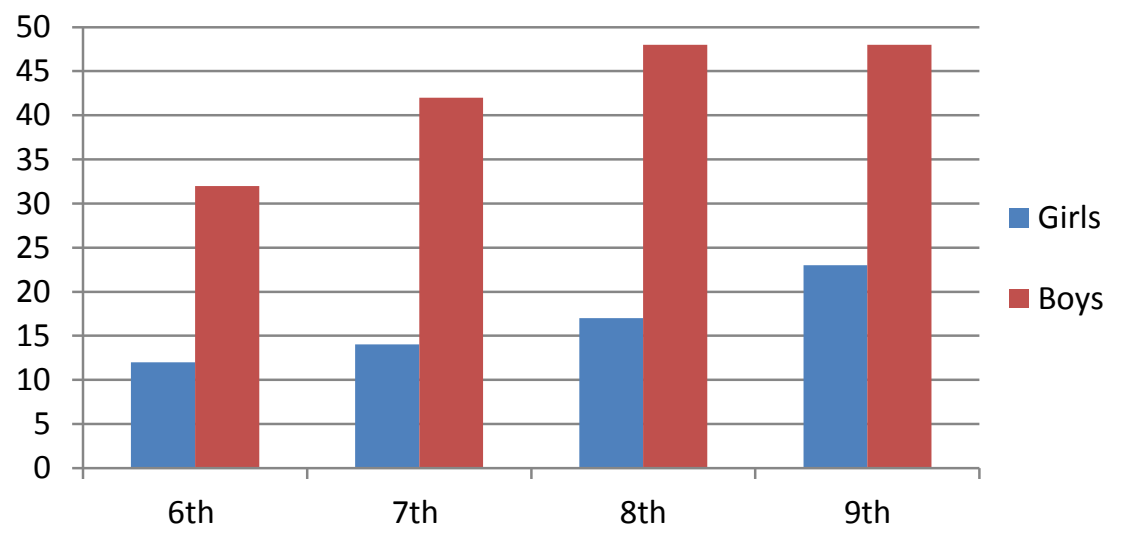


Chart 5: Total number of exclusions per grade and gender

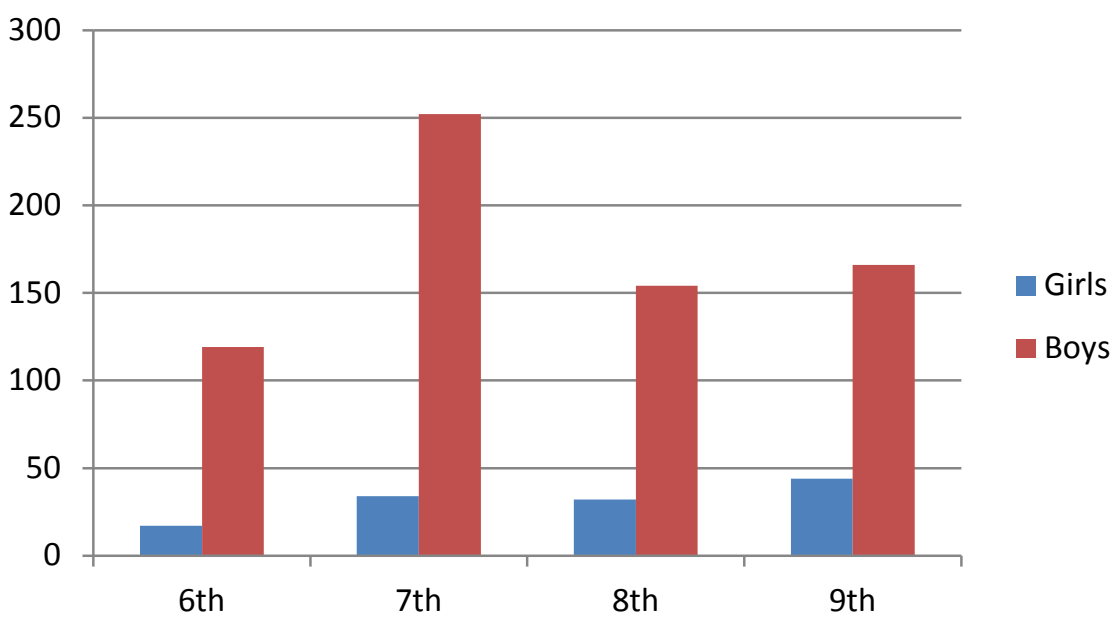

What is interesting to note here is the fact that the majority of boy exclusions take place in the $7^{\text {th }}$ grade. Can a link be established with what S. Ayral (2011) qualified as the rites of passage ? In the $6^{\text {th }}$ grade, girls are rarely expelled (17 times), as opposed to boys, over 7 times more (119 times). From the beginning of high school, an important difference in behavior between boys and girls can be noticed. In the $7^{\text {th }}$ grade for example, the number of exclusions doubles for girls (from 17 to 34) : there are twice as many exclusions, for roughly the same number of girls (12 in the $6^{\text {th }}$ grade, 14 in the $7^{\text {th }}$ grade). On the other hand, if the number of exclusions for boys almost doubles too (119 in the $6^{\text {th }}$ grade and 252 in the $7^{\text {th }}$ grade), the number of expelled jumps from 32 to 42 , showing an increase of $32 \%$ of male pupils excluded.

Two rites of passage may help in understanding this phenomenon : first of all, the validation ritual set in place by peers. In order to be accepted and welcomed as a "true man", the young boy must multiply provocations towards the adults. There is also the proximity of girls that urges them to behave as "bad boys". This second hypothesis verifies itself mainly in the top classes, therefore one cannot be certain it may serve to explain this tendency. It is also to be noticed that the number of exclusions decreases for boys in the $8^{\text {th }}$ and $9^{\text {th }}$ grade, while for girls, there is a slight increase of exclusions every year. Nevertheless the gaps are minor and it is therefore difficult to draw any general conclusions on the behavior of pupils or the sanction methods.

However, in putting in relation the number of expelled pupils and exclusions, the figures show a certain tendency: the chart of averages below proves the predominance, for all genders, of exclusions in the $7^{\text {th }}$ grade. 
Chart 6: Means of exclusions per expelled pupil

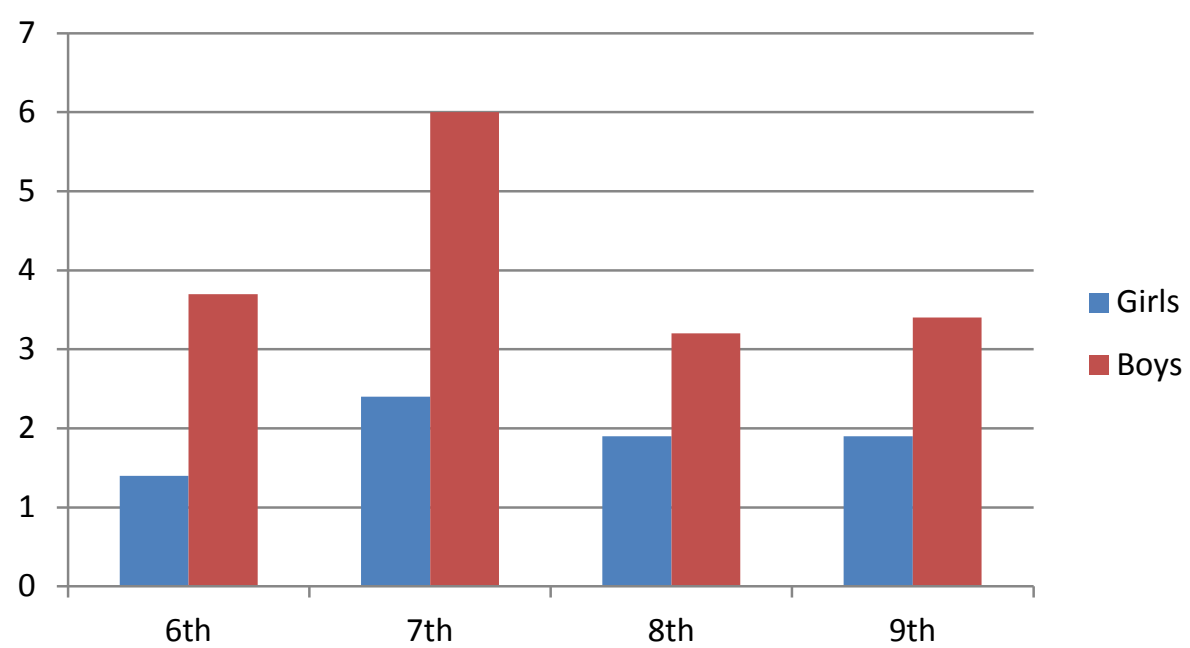

Based on the average of exclusions per expelled pupil, it can be noticed that the "ideal type" (in reference to Mr. Weber, 1905) in this particular middle school is a $6^{\text {th }}$ grader girl, and that the "anti-ideal type" is a $7^{\text {th }}$ grader boy.

Figure 1: The ideal type

Ideal type

Anti-ideal type

Girls 6th Girls 8th Girls 9th Girls 7th Boys 8th Boys 9th Boys 6th Boys 7th

\subsubsection{Exclusion figure results}

Chart 7: The various exclusion motives in relation to the grade and gender of the pupils

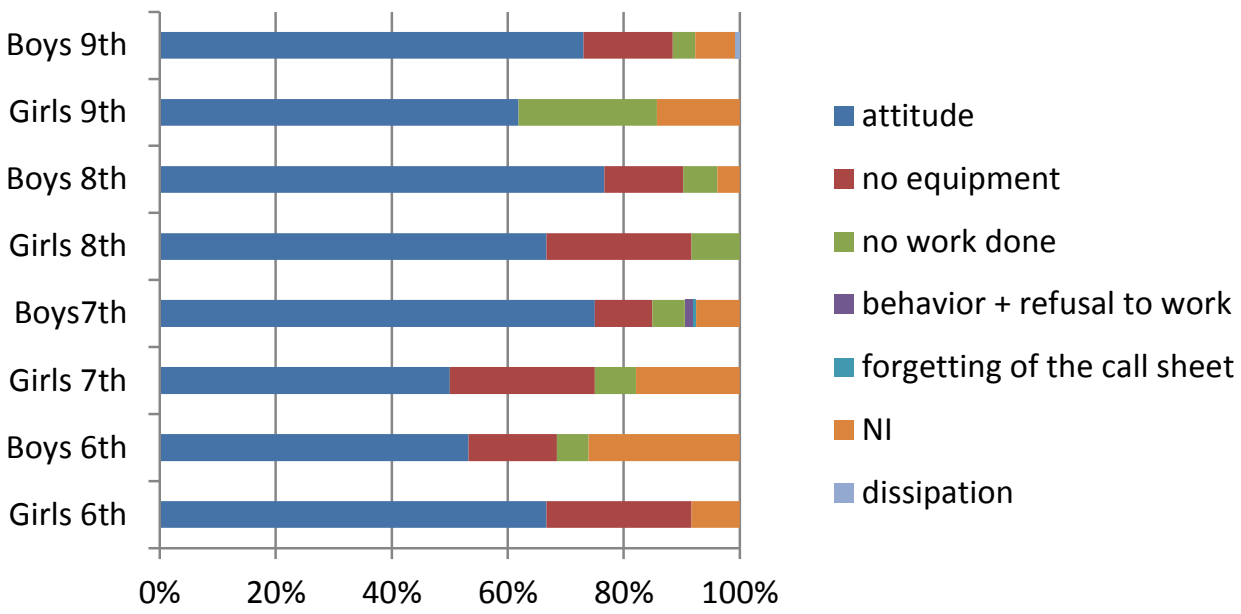


The chart above calls to mind the various motives for exclusion and their percentage, thus setting in evidence the predominance of the "attitude" motive. Yet it is necessary to specify that the various motives are not, in fact, highly varied, and that the software does not require any additional information regarding breaches. It is thus necessary to handle the data with care as it is not entirely reliable in revealing the pupils' behavior (too general).

The "attitude" motive is wide-spread for every grade and every gender, with the exception of $7^{\text {th }}$ grader girls, where it only represents $50 \%$. The motive "no work done" is also very present for $9^{\text {th }}$ grader girls, and the motive "lack of equipment" is often seen in the $7^{\text {th }}, 8^{\text {th }}$, and $9^{\text {th }}$ graders. This is not necessarily the case for boys. S. Ayral (2011) notices gender motives regarding pupil punishments: boys are more prone to incivilities, violence, degradation, etc, while girls are mainly punished for their lack of work, of equipment, for gossiping, using cellphones, etc. One can observe the same motives for exclusion.

\subsubsection{Remark on the gender of the teachers}

The chart below draws a parallel between the percentage of pupils excluded by female teachers and the percentage of pupils excluded by male teachers, while taking into account the gender of the pupils. One may notice that both male and female teachers expel more boys $(86,89$ $\%$ for the women, and $73,82 \%$ for the men), and that the women in particular hold the highest rates of exclusion. Regarding girls, the male teachers expel the most, mainly $26,18 \%$ compared to $13,11 \%$ for the female teachers.

Chart 8: Percentage of exclusions by the male and female teachers for pupils of both gender

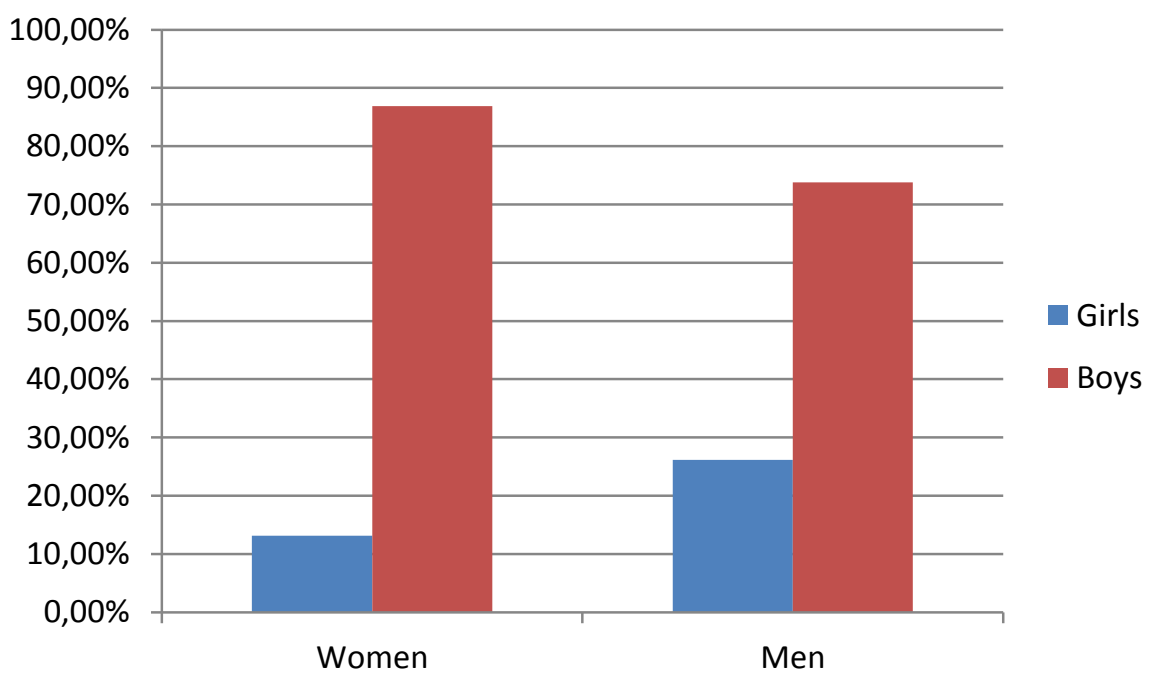

The two charts below cross over the percentage of sanctions according to the teacher's gender, as well as the grade and gender of the pupils. 
Chart 9: Female teachers

\begin{tabular}{ccc}
\hline \multicolumn{3}{c}{ FEMALE TEACHERS } \\
\hline $\begin{array}{c}\text { Total of exclusions } \\
\text { Grades }\end{array}$ & Gender \\
$9^{\text {th }}$ & $18,24 \%$ & Boy \\
$8^{\text {th }}$ & $10,43 \%$ & $\mathbf{8 1 , 7 6 \%}$ \\
$7^{\text {th }}$ & $11,67 \%$ & $89,57 \%$ \\
$6^{\text {th }}$ & $11,54 \%$ & $88,33 \%$ \\
Global total & $\mathbf{1 3 , 1 1 \%}$ & $88,46 \%$ \\
\hline
\end{tabular}

The teacher chart sets in evidence a rise in the numbers of girls expelled in the $9^{\text {th }}$ grade $\left(18,24 \%\right.$ compared to $10,43 \%$ in $8^{\text {th }}$ grade), and a decrease in the numbers of boys expelled in the same grade $\left(81,76 \%\right.$ whereas in $8^{\text {th }}$ grade it was $\left.89,57 \%\right)$.

This rise in the numbers of girls expelled by female teachers could be explained by the development of feelings of rivalry between them and the teacher or by the need to assert themselves as they grow older.

Chart 10: Male teachers

\begin{tabular}{ccc}
\hline \multicolumn{3}{c}{ MALE TEACHERS } \\
\hline Total of exclusions & \multicolumn{2}{c}{ Gender } \\
Grades & Girl & Boy \\
$9^{\text {th }}$ & $33,33 \%$ & $66,67 \%$ \\
$8^{\text {th }}$ & $32,76 \%$ & $67,24 \%$ \\
$7^{\text {th }}$ & $17,02 \%$ & $\mathbf{8 2 , 9 8 \%}$ \\
$6^{\text {th }}$ & $17,14 \%$ & $\mathbf{8 2 , 8 6 \%}$ \\
Global total & $\mathbf{2 6 , 1 8 \%}$ & $\mathbf{7 3 , 8 2 \%}$ \\
\hline
\end{tabular}

The chart above underlines the rise of exclusions (which nearly doubles) regarding $8^{\text {th }}$ and $9^{\text {th }}$ grader girls. At the same time, one can notice a decrease in exclusions for $8^{\text {th }}$ and $9^{\text {th }}$ grader boys (from $83 \%$ to circa $67 \%$ ). What hypothesis can be drawn from these results ? Are young girls calmer in the lower grades (namely the $6^{\text {th }}$ and $7^{\text {th }}$ ) ? At the beginning of high school, do young boys have something to prove by making themselves noticeable ? Strangely, the curb inverses itself in the $8^{\text {th }}$ and $9^{\text {th }}$ grade where there is a significant decrease in expelled boys. Are certain young girls trying to stand out in the eyes of their male teachers?

In both charts above, a global trend sees the fact that girls are often more expelled as they grow older, while boys tend to be less punished, whether it is by a male or female teacher. One explanation could be the specificity of the pupils that year, a change occurring from one year to the next. It would thus be necessary to re-enact the study several years in a row to be able to obtain reliable conclusion. 
Chart 11: Average of exclusions per pupil gender and per expelling teacher

\begin{tabular}{cccc}
\hline & \multicolumn{3}{c}{ EXPELLING TEACHER } \\
\hline & Women & Men & Average \\
Girl pupils & $\mathbf{1 , 4 7}$ & $\mathbf{2}$ & $\mathbf{1 , 7 4}$ \\
Boy pupils & $\mathbf{9 , 7 6}$ & $\mathbf{5 , 6 4}$ & $\mathbf{7 , 7}$ \\
Total & 11,23 & 7,64 & \\
\hline
\end{tabular}

With an average of 11,23 pupils expelled, the female teachers are more active than their male colleagues. Yet the men expel more girls than the women, and not as many boys (would indulgence go hand in hand with gender identity ?). In spite of these differences, boys focus the major part of the exclusions, which are handed out by female teachers.

\section{CONCLUSION}

The study allows one to notice the considerable road still lying ahead in shaping a school system that would not convey stereotypes and prejudice anymore. Punishment, just as toys, playground, orientation etc., is gender-based. Pupils of both genders are exposed early on in high school to a stereotypical vision of themselves filled with preconceived ideas about their genders. The brutal boy whose behavior is tolerated on behalf of his gender and who unconsciously (or not) toys with the function he was attributed, and the girl who locks herself in a role for which admiring the impertinent boy facing the teacher is perceived as a positive thing among her peers, are commonplace in the everyday life of this high school. To make matters worse, all teachers are not aware of the gender-based remarks they target their pupils with.

This study illustrates the general tendency in which boys are more often expelled from class than girls, even if boys are perhaps more boisterous till the $7^{\text {th }}$ grade, and girls more agitated in the $8^{\text {th }}$ and $9^{\text {th }}$ grade.

In parallel, one can notice that it is the female teachers who expel the most, particularly boys, the male teachers tending to expel girls. The study questions each adults' role when faced with the possibility of punishment in high school, as determination harms the pupils who do not wish to "fit in". Finally, the fact the educational space today is occupied by a majority of women should also be noticed.

\section{ACKNOWLEGEMENTS}

The authors would like to express their thankfulness to the AREF, FDE, LIRDEF and Université de Montpellier. 


\section{BIBLIOGRAPHY}

1. Auduc, J.-L., (2009). Sauvons les garçons, Paris : Descartes \& Cie.

2. Ayral, S., (2011). La fabrique des garçons, Paris : Presses universitaires de France.

3. Ayral, S., (2011). Le sexe des sanctions, Les Cahiers pédagogiques, 487, 42-43.

4. Bourdieu, P., (1998). La domination masculine, Paris : Seuil.

5. De Boissieu, C., (2009). Sexes et genres à l'école maternelle, Recherches \& éducations, 13 p.

6. Desplats, M., (1989). Les femmes et la physique, Thèse en Sciences de l'éducation, Université de Strasbourg.

7. Duru-Bellat, M., (1994). Filles et garçons à l'école, approches sociologiques et psychosociales. In : Revue française de pédagogie, 109, 111-141.

8. Establet, R. \& Baudelot, C., (2007). Quoi de neuf chez les filles ?, Paris : Nathan.

9. Establet, R. \& Baudelot, C., (1997). Allez les filles, Paris : Points.

10. Foucault, M., (1975). Surveiller et punir, Paris : Gallimard.

11. Belotti, E. G., (1973). Du côté des petites filles, Paris : Edition des femmes.

12. Isabelle, K., (2010). Pourquoi la mixité dans les classes ne provoque-t-elle pas spontanément l'égalité de traitement entre les filles et les garçons ? Tréma, 32.

13. Monnot, C., (2009). Petites filles, l'apprentissage de la féminité, Paris : Edition Autrement.

14. Mosconi, N., (2004). Effets et limites de la mixité scolaire, Travail, genre et sociétés, 1, 11, 165-174.

15. Mosconi, N., (2001). Comment les pratiques enseignantes fabriquent de l'inégalité entre les sexes. Les Dossiers des sciences de l'éducation, 1, Toulouse : P. Univ. du Mirail.

16. Mosconi, N., (1989). La mixité dans l'enseignement secondaire : un faux semblant ? Paris: PUF.

17. Okley, A., (1972). Sex, Gender and Society, In : Fournier, M. (Ed.) Hommes, femmes, quelles differences?, Sciences humaines, 146, 22-24.

18. Pain, J., (1972). Chronique de l'école caserne, Paris : Champ social.

19. Prairat, E., (1997). Petites médiations à l'usage des éducateurs, Paris : L'Harmattan.

20. PISA (2009). http://www.oecd.org/pisa/46624382.pdf 